\title{
Spreading Good Words: The Mediating Effect of Brand Loyalty between Role Model Influence and Word of Mouth
}

\author{
Mei-Chi Macy Wong \\ The Hong Kong Polytechnic University \\ E-Mail: spmacy@speed-polyu.edu.hk \\ Man-Lung Jonathan Kwok \\ The Hong Kong Polytechnic University \\ E-Mail: spjonk@speed-polyu.edu.hk \\ Mei Mei Lau \\ The Hong Kong Polytechnic University \\ E-Mail: spmay@speed-polyu.edu.hk
}

\begin{abstract}
Many businesses around the world spend millions of dollars every year on celebrity endorsement deals in order to associate their products or brands with some of the biggest names in sport. Indeed, in a crowded media environment, marketers face the challenge of attracting consumers' attention, and one way of doing this is to use celebrities because they have the ability to break through this media clutter, contribute to brand name recognition, and create meaning for their products. The aim of this study is to examine how sport celebrities acting as role models influence young customers' behavioral intentions; namely, word-of-mouth behavior and brand loyalty. A convenience sampling was drawn from young adults, with 468 valid responses. Results indicate that endorsements of athlete role models have a positive influence on young adults' positive word-of-mouth behavior and brand loyalty. Moreover, the study found that brand loyalty partially mediated the relationship between role model influence and positive word of mouth. This study provides useful insights on how young consumers in Hong Kong respond to the use of sport celebrities in marketing programs.
\end{abstract}

Keywords: Sport Celebrities, Word of Mouth, Role Model, Brand Loyalty 


\section{INTRODUCTION}

Sports celebrities are a worldwide phenomenon marketing professionals have used extensively as part of their advertising strategies. According to Global Industry Analysts (2013), the world sports apparel industry is expected to have annual sales of more than US $\$ 126$ billion in 2015. This highly competitive and active market is driven by a trend towards healthier lifestyles (Global industry Analysts Inc., 2013), and businesses are willing to spend millions in endorsement deals to benefit brands, create positive associations, contribute to brand name recognition, and create meaning for their products (Carlson and Donavan, 2008; Dix, Phau and Pougnet, 2010). Pringle (2004) has reported a substantial rate of return by using the celebrity endorsement strategy, that is, 27 times its costs. From an economic perspective, consistent findings are found on the link between stock market value and celebrity endorsements (Chung, Derdenger, and Srinivasan, 2013; Ding, Molchanov, and Stork, 2011; Elberse and Verleun, 2012; Garthwaite, 2014; Popescu, 2014). However, a direct relationship between the use of sports celebrities in commercials and positive outcomes (such as positive word of mouth and brand loyalty) has yet to be confirmed before organizations engage in these high investments related to the expenses involving celebrities (Grohmann, Battistella and Radons, 2013).

Not surprisingly, the young public (i.e., generation $\mathrm{Y}$ ) is more affected by sports celebrities, but at the same time is more resistant to marketing strategies. Many researchers have realized the importance of better understanding the consumption behavior of generation Y (Belleau et al., 2007; Bush et al., 2004; Grohmann et al., 2013). Athletes are effective as endorsers as they often represent an association with a symbolic aspirational reference group (Kamins, 1990). The young public may rely on such reference groups as points of comparison to assess their own attitudes and behaviors (Carlson and Donavan, 2008). In view of this, our research seeks to investigate how sports celebrities as role models influence young adult consumers' behavioral intentions (i.e., word-of-mouth behavior and brand loyalty). Thus, this study aims to address three research questions: How do sports celebrities influence young customers' behavioral intentions; how do sports celebrities affect positive word of mouth; and how does brand loyalty relate to sports celebrities?

\section{LITERATURE REVIEW AND HYPOTHESES DEVELOPMENT}

Young adults aged between 17 and 24 years consume more than $\$ 153$ billion dollars per year (Brand, 2000), as they love to be entertained by sports, movies, and the Internet (Bush et al., 2005). Accordingly, this segment is an enticing target market for sport marketers. Indeed, goods endorsed by sports celebrities have a great 
influence on the total weekly expenditure of 36 percent of young Australian adults (Dix et al., 2010). Previous studies have focused on the influence and effectiveness of sports endorsers, but very few have considered the impact of sports celebrities as role models on young consumers, especially in the Hong Kong context. Basically, celebrities are well-known individuals who receive significant media attention (Jin and Phua, 2014), while a celebrity endorser is an individual who enjoys public recognition in relation to a consumer good by promoting it in an advertisement (McCracken, 1989). This study aims to bridge this gap and provide insights to understand whether sports endorsers as role models, via the consumer socialization process, exert a significant influence on the behavioral intentions of young adults.

Based on social cognitive theory, people are highly affected by others' experience and behavior (Grohmann et al., 2013). Sports celebrities are influential socialization agents and role models whose behaviors, attitudes and skills attract young consumers, who view the celebrities as highly dynamic people with likable qualities (Byrne, Whitehead and Breen, 2003; Chan, 2008). Previous studies have considered various paradigms to understand the effects of celebrity endorsement, including source credibility (Hung, 2014), source attractiveness (Ohanian, 1990), meaning transfer (McCracken, 1986), and image congruence (Biswas, Biswas and Das, 2006). Many models and theories on celebrity endorsement have emphasized endorser-product relationships and endorser-audience relationships that play a major role in how well endorsement messages influence audiences (Charbonneau and Garland, 2005). According to the product match-up hypothesis, endorsement is most effective when there is a match between celebrity personality characteristics and brand attributes (Ahmed et al., 2012).

Most endorser studies follow the postulates of the elaboration likelihood mode (ELM), a cognitive and celebrity-focused model, where a celebrity's attributes would receive elaborate or heuristic processing when the perceived attributes were deemed relevant to the consumers' decision making (Petty and Wegener, 1999). Based on ELM, brand endorsement effects consider source attractiveness, source credibility, and image congruence to enhance endorsed brand attitude (Hung, 2014). Furthermore, the meaning transfer model advocates that when a celebrity endorses a product, the meaning associated with the endorser would transfer to the product, and in turn, transfer this meaning to the consumer (Brajesh and Gouranga, 2011). Indeed, many models have reinforced the concept of associative learning (ALT); that is, "the pairing of two stimuli can affect how people feel about at least one of the stimuli" (Dix, et.al., 2010 , p. 39). According to ALT theory, celebrities and brands occupy nodes in one's 
memory, which become connected over time through the endorsement process (Magnini, Honeycutt, and Cross, 2008).

Behavioral intentions are outcomes of the socialization process. Advertisers are particularly concerned with the favorable and unfavorable behaviors consumers might exhibit towards a brand (Bush et al., 2004). For instance, when consumers praise a brand and express preference for one advertiser over others, these favorable intentions lead to paying premium prices, spreading positive word of mouth, and displaying brand loyalty (Bush, et al., 2004). According to Zeithaml, Berry, and Parasuraman (1996), behavioral intentions should be measured using a multi-dimensional construct. For the present study, two dimensions have been considered to define behavioral intentions: positive word of mouth and brand loyalty.

Social interaction is one of the three main sources of consumption learning (Churchill and Moschis, 1979). Young consumers tend to acquire their abilities, knowledge, and relevant attitudes as consumers through consumption socialization in the marketplace, family and friends, peers, and the media (Ward, 1974). As people often rely on the opinions of others who are perceived as not having vested interests, word of mouth is an important platform in influencing behavioral intentions. Word of mouth (WOM) is defined as person-to-person oral communication between a receiver and a communicator whom the receiver perceives as non-commercial regarding a brand, product, or service (Buttle, 1998). In recent years, word-of-mouth communication has not been limited to the use of the oral channel but has also appeared on social platforms, such as the Internet and Facebook (Hardey, 2011; Radighieri and Mulder, 2013). Extant work indicates that WOM plays a significant role in influencing consumers as it is linked to satisfaction (Anderson, 1998), loyalty (Samson, 2006; Samson 2010), and purchase behaviors (Brown and Reingen, 1987). Many companies are now using word-of-mouth marketing, also known as buzz marketing, to spread good words to potential customers through celebrity endorsers, satisfied customers, and opinion leaders such as bloggers. Based on the above discussion, it is hypothesized that:

H1: The influence of athlete role models on young adults is positively related to positive word-of-mouth behavior.

Brand loyalty indicates that customers have positive attitudes towards a brand, and are willing to repurchase the same merchandise or service from the same brand, regardless of the actions of competitors or changes in the environment (Liu, 2007). There are two brand loyalty dimensions: attitudinal and behavioral loyalty (Chaudhuri and Holbrook, 2001; Dick and Basu, 1994). Attitudinal loyalty leads to consumers' 
willingness to buy at higher prices and overcome obstacles to purchase (Bandyopadhyay and Martell, 2007). Behavioral loyalty is the actual action of repeat purchase, and it reflects true commitment to a specific brand (Quester and Lim, 2003). Although changes in marketing strategies and environments can affect consumers' purchase behavior, loyal customers will still continue and repeat purchasing their favorite brands. This represents a barrier to entry and acts as a basis for charging at a price premium. Based on this discussion, it is further hypothesized that:

H2: The influence of the athlete role model on young adults is positively related to brand loyalty.

H3: Brand loyalty is favorably related to positive word-of-mouth behavior.

This study has further considered whether there is an observed relationship between an independent variable and a dependent variable via the inclusion of a third explanatory variable, the mediator (MacKinnon, 2008). Indeed, the power of brand loyalty cannot be under-estimated as it is a core dimension of brand equity. Brand loyalty is more than simply repurchasing as it promotes word-of-mouth advocacy and lowers advertising costs (Dick and Basu, 1994). Thus, it is hypothesized that:

H4: Brand loyalty mediates the relationship between role model influence and positive word-of-mouth behavior.

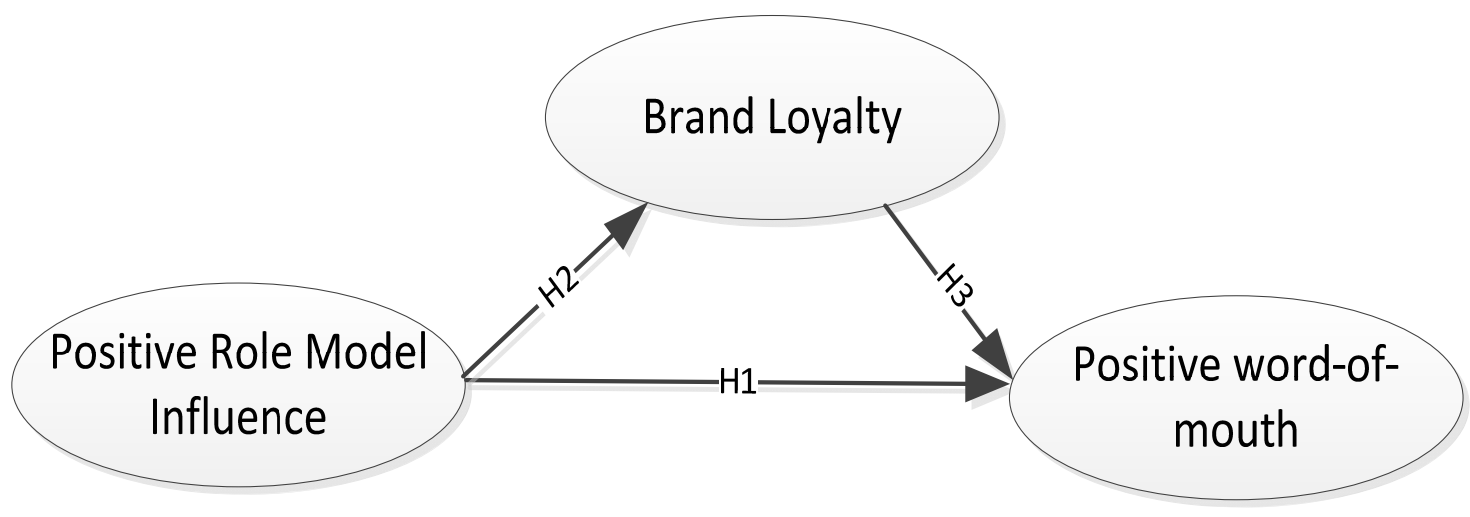

Figure 1 The Theoretical Model of This Study

\section{RESEARCH METHOD AND DATA ANALYSIS}

\section{Data Collection and Sample}

This study focuses on young adults aged between 16 and 24 residing in Hong Kong. A convenience sampling was drawn from this target group via an online questionnaire. A total of 468 teenagers voluntarily participated in the survey. 
Hypotheses 1 to 3 were tested using regression with SPSS software, and the mediating relationship (Hypothesis 4) was analyzed using the method from Baron and Kenny (1986). To provide a more rigorous result for the mediating relationship, SPSS Macro (PROCESS) (Hayes, 2013) was adopted. Sobel's (1982) test was performed as well to determine whether there is full or partial mediation.

\section{Measures}

All the measures were adapted from previous studies and measured on a sevenpoint Likert scale, where 1 represents "strongly disagree" and 7 represents "strongly agree." The four-item scale of role model influence was adapted from Rich (1997). The three-item scale of positive word of mouth was adapted from Zeithaml et al. (1996). The three-item scale of brand loyalty was adapted from Zeithaml et al. (1996). For all of the measures, since all of the reliabilities were larger than .70, we aggregated the multi-items and computed a single construct related to each variable.

\section{RESULTS}

\section{Descriptive Statistics, Correlation, and Reliabilities}

There was a balanced sample in terms of gender, with $41.9 \%$ male and $56.8 \%$ female. All of the respondents were between the ages of 16 and 24 .

Table 1 shows the results of bivariate correlations among the constructs and reliabilities. All of the variables achieved a level of 0.7 in reliability analysis.

Table 1 Bivariate Correlations and Reliabilities of The Constructs

\begin{tabular}{lccccc}
\hline Variables & $\mathrm{M}$ & $\mathrm{SD}$ & 1 & 2 & 3 \\
\hline 1. Role model & 5.04 & 1.54 & $(.95)$ & & \\
2. Brand loyalty & 5.51 & 1.21 & .70 & $(.83)$ & \\
3. Positive word-of-mouth & 5.68 & 0.95 & .63 & .68 & $(.85)$ \\
\hline
\end{tabular}

Notes: $N=468$. Reliabilities are in parentheses.

For all correlations above, $p \leqslant 01$.

\section{Results Related to The Hypotheses}

Several conditions have to be fulfilled to support all the hypotheses. First, the independent variable has to be directly related to the mediator. From Table 2, positive role model influence should be directly related to brand loyalty; secondly, the mediator has to be related to the dependent variable; that is, brand loyalty has to be related to positive word of mouth. Finally, when mediator is present, the direct 
relationship between the independent variable and the dependent variable will be reduced, which demonstrates a partial mediation, or reduced to zero, which demonstrates a full mediation. Thus, in the theoretical model, if brand loyalty is present in the analysis, and if the direct effect of role model and positive word of mouth reduces either to zero or a smaller size, then it indicates that brand loyalty is the mediator (Baron and Kenny, 1986). Table 2 shows the results of the regression analysis.

Table 2 Results of Regression Analysis

\begin{tabular}{|c|c|c|c|}
\hline & Model 1 & Model 2 & Model 3 \\
\hline Variables & Brand loyalty & Positive WOM & Positive WOM \\
\hline \multicolumn{4}{|l|}{ Direct effects } \\
\hline Role model & $.55 * *$ & $.39 * *$ & $.19 * *$ \\
\hline \multicolumn{4}{|l|}{ Mediation effects } \\
\hline Brand loyalty & & & $.53 * *$ \\
\hline$\Delta \mathrm{R}^{2}$ & & & .05 \\
\hline Overall $\mathrm{R}^{2}$ & .49 & .39 & .51 \\
\hline Overall model F & $439.32 * *$ & $309.01 * *$ & $240.70 * *$ \\
\hline
\end{tabular}

Hypothesis 1 (see Table 2 ) states that positive role model influence is positively related to positive word of mouth (Model 2; $\beta=.39, p<.01$ ). Model 1 shows that Hypothesis 2 is also significant, suggesting that positive role model influence is positively related to brand loyalty $(\beta=.55, p<.01)$. Table 2 also shows support for Hypothesis 3 (Model 3), stating that brand loyalty is positively related to positive word of mouth $(\beta=.53, p<.01)$. Finally, for the mediation analysis, the above significant hypotheses have already satisfied the first two steps stated in Baron and Kenny (1986). The final step in Model 3 shows that the direct effect of positive role model and positive word of mouth has been reduced, but remains significant $(\beta=.19$, $p<.01)$ when brand loyalty is introduced into the analysis, indicating a partial mediation. Therefore, brand loyalty partially mediated the effect of positive role model and positive word of mouth.

We also performed SPSS Macro (PROCESS) (Hayes, 2013) and Sobel's (1982) test to provide substantial support for indirect mediation. To show the indirect effect in Hypothesis 3, the upper and lower confidence interval should be assessed (Hayes, 2013). The lower confidence interval and upper confidence interval are .15 and .25, respectively. And the result of Sobel (1982) test indicates that brand loyalty is found 
to partially mediate the relationship between positive role model and positive word of mouth $(z=9.16, p=.00)$

\section{DISCUSSION}

According to the results, the determinants of positive word of mouth include positive role model influence and brand loyalty, and there is a partial mediating effect among the three constructs. An influencing agent in an endorsement situation can affect individuals to adopt attitudes due to an internalization process. Internalization indicates that based on an individual's belief in another person, she/he is willing to conform to the attitude or behavior advocated by this person (Friedman and Friedman, 1979). Therefore, the study results are consistent with internalization theory because they show that when consumers believe in their favorite sport celebrities, they are willing to conform to the attitude or behavior of such role models and should then spread positive word of mouth and remain loyal to the advertised brands or products.

\section{Practical Implications}

Indeed, a spokesperson's credibility is critical in determining whether or not consumers make internal attributions (Dix et al., 2010). Sport endorsers who are perceived as role models for young adults are more trustworthy, and thus, more capable of affecting purchase behaviors and intentions (Dix et al., 2010). This reinforces one of the renowned models related to celebrity endorsement - the source model (i.e., the source attractiveness model and the source credibility model). In order to increase sales of brands or products, marketers should choose sport endorsers who have become popular recently and who have a healthy image. They should also be very careful in selecting their endorsers to avoid any negative effects from individuals' behavior. Moreover, when celebrities endorse multiple brands, the endorser effects are cast in doubt. The concern of over-endorsement and finding appropriate endorsers are challenges advertisers have to face (Hung, Chan, and Tse, 2011).

\section{Future Research}

Several issues associated with the limited time frame and costs in this study require further research considerations. First, the sample composition applies mainly to generation Y. Future studies could focus on different segments of consumers and cover different user characteristics, such as hobbies, innovativeness of consumers, Internet usage, and time using smartphones. Consumers now devote most of their time to online social networks, discussion forums, and online review reports. These could 
probably affect their word-of-mouth recommendations, as well as brand loyalty. Therefore, external influences can also be studied in future research.

\section{REFERENCES}

Ahmed, A., Mir, F.A. \& Farooq, O. (2012). Effect of celebrity endorsement on customers' buying behavior: A perspective from Pakistan, Interdisciplinary. Journal of Contemporary Research in Business, 4(5), 584-592.

Anderson, E.W. (1998). Customer satisfaction and word of mouth. Journal of Service Research, 1(1), 5-17. http://dx.doi.org/10.1177/109467059800100102

Bandyopadhyay, S. \& Martell, M. (2007). Does attitudinal loyalty influence behavioral loyalty? A theoretical and empirical study. Journal of Retailing and Consumer Services, 14(1), 35-44. http://dx.doi.org/10.1016/j.jretconser.2006.03.002

Baron, R.M. \& Kenny, D.A. (1986). The moderator-mediator variable distinction in social psychological research: Conceptual, strategic, and statistical considerations. Journal of Personality and Social Psychology, 51(6), 1173-1182. http://dx.doi.org/10.1037/0022-3514.51.6.1173

Belleau, B.D., Summers, T.A., Xu, Y. \& Pinel, R. (2007). Theory of reasoned action: Purchased intention of young consumer. Clothing Textiles Research Journal, 25(3), 244-257. http://dx.doi.org/10.1177/0887302X07302768

Biswas, D., Biswas, A., and Das, N. (2006). The differential effects of celebrity and expert endorsements on consumer risk perceptions: The role of consumer knowledge, perceived congruency, and product technology orietnation. Journal of Advertising, 35(2), 17-31. http://dx.doi.org/10.1080/00913367.2006.10639231

Brown, J. and Reingen, P. (1987). Social ties and word-of-mouth referral behavior. Journal of Consumer Research, 14(3), 350-362. http://dx.doi.org/10.1086/209118

Brajesh, K. and Gouranga, P. (2011). Celebrity endorsement in FMCGs advertising: A case study in a culturally vibrant society. Advances in Management, 4(8), 24-28.

Brand, R., (2000). Advertisers examine teens and their spending clout. Retrieved July 23, 2014, from http:/www.tcpalm.com/business/01jteenu.shtml.

Bush, A.J., Martin, C.A. \& Bush, V.D. (2004). Sports celebrity influence on the behavioral intentions of generation Y. Journal of Advertising Research, 1(44), 108-118. http://dx.doi.org/10.1017/S0021849904040206

Bush, V.D., Bush, A.J., Clark, P. \& Bush, R.P. (2005). Girl power and word-of-mouth behavior in the flourishing sports market. Journal of Consumer Marketing, 22(4/5), 257-264. http://dx.doi.org/10.1108/07363760510611680 
Buttle, F.A. (1998). Word of Mouth: Understanding and Managing Referral Marketing. Journal of Strategic Marketing, 6(3), 241-254. http://dx.doi.org/10.1080/096525498346658

Byrne, A., Whitehead, M. \& Breen, S. (2003). The naked truth of celebrity endorsement. British Food Journal, 105(4/5), 288-296. http://dx.doi.org/10.1108/00070700310477086

Carlson, B. and Donavan, T. (2008). Concerning the effect of athlete endorsements on brand and team-related intentions. Sport Marketing Quarterly, 17(3), 154-162.

Chan, K. (2008). Social comparison of material possessions among adolescents. Qualitative Market Research: An International Journal, 11(3), 316-330. http://dx.doi.org/10.1108/13522750810879039

Charbonneau, J. \& Garland, R. (2005). Talent, looks or brains? New Zealand advertising practitioners' views on celebrity and athlete endorsers. Marketing Bulletin, 16(3), 1-10.

Chaudhuri, A. \& Holbrook, M.B. (2001). The chain of effects from brand trust and brand affect to brand performance: the role of brand loyalty. Journal of Marketing Management, 65(2), 81-93. http://dx.doi.org/10.1509/jmkg.65.2.81.18255

Chung, K., Derdenger, T. and Srinivasan, K. (2013). Economic value of celebrity endorsements: Tiger Woods' impact on sales of Nike goft balls. Marketing Science, 32(2), 271-293. http://dx.doi.org/10.1287/mksc.1120.0760

Churchill, G. \& Moschis, G.P. (1979). Television and interpersonal influences on adolescent consumer learning. Journal of Consumer Research, 6(1), 23-35. http://dx.doi.org/10.1086/208745

Dick, A. \& Basu, K. (1994). Customer loyalty: toward an integrated conceptual framework. Journal of the Academy of Marketing Science, 22(2), 99-113. http://dx.doi.org/10.1177/0092070394222001

Ding, H., Molchanov, A. and Stock, P. (2011). The value of celebrity endorsements: A stock market perspective. Marketing Letters, 22(2), 147-163. http://dx.doi.org/10.1007/s11002-010-9117-y

Dix, S., Phau, I. \& Pougnet, S. (2010). Bend it like Beckham': the influence of sports celebrities on young adult consumers. Young Consumers, 11(1), 36-46. http://dx.doi.org/10.1108/17473611011025993

Elberse, A. and Verleun, J. (2012). The economic value of celebrity endorsements. Journal of Advertising Research, 52(2), 149-165. http://dx.doi.org/10.2501/JAR-52-2-149-165 
Friedman, H.H. \& Friedman, L. (1979). Endorser effectiveness by product type. Journal of Advertising Research, 19(5), 63-71.

Garthwaite, C. (2014). Demand spillovers, combative advertising, and celebrity endorsements. American Economic Journal: Applied Economics, 6(2), 76-104. http://dx.doi.org/10.1257/app.6.2.76

Global industry Analysts Inc., (2013). Global Sports and Fitness Clothing Industry, Global Sports Apparel Market - Present and Future Outlook II-1. Retrieved July 23, 2014, from http://www.reportlinker.com/ci02121/Sport-Clothing-andAccessories.html.

Grohmann, M.Z., Battistella, L.F. \& Radons, D.L. (2013). Sports celebrities influencing the consumption of young people in the Brazilian context. African Journal of Business Management, 7(24), 2351-2361.

Hardey, M. (2011). Generation C. International Journal of Market Research, 53(6), $749-770$.

Hayes, A.F. (2013). Introduction to Mediation, Moderation, and Conditional Process Analysis. The Guilford Press, New York.

Hung, K., Chan, K. and Tse, C. (2011). Assessing celebrity endorsement effects in China. Journal of Advertising Research, 51(4), 608-623.

Hung, K. (2014). Why celebrity sells: A dual entertainment path model of brand endorsement. Journal of Advertising, 43(2), 155-166. http://dx.doi.org/10.1080/00913367.2013.838720

Jin, S. and Phua, J. (2014). Following celebrities' tweets about brands: The impact of Twitter-based electronic word-of-mouth on consumers' source credibility perception, buying intention, and social identification with celebrities. Journal of Advertising, 43(2), 181-195. http://dx.doi.org/10.1080/00913367.2013.827606

Kamins, M. (1990). An investigation into the 'match-up' hypothesis in celebrity advertising: When beauty may be only skin deep. Journal of Advertising, 19(1), 4-13. http://dx.doi.org/10.1080/00913367.1990.10673175

Liu, Y. (2007). The long-term impact of loyalty programs on consumer purchase behavior and loyalty. Journal of Marketing, 71(4), 19-35. http://dx.doi.org/10.1509/jmkg.71.4.19

MacKinnon, D.P. (2008). Introduction to Statistical Mediation Analysis. Erlbaum, New York.

Magnini, V., Honeycutt, E., and Cross, A. (2008). Understanding the use of celebrity endorsers for hospitality firms. Journal of Vacation Marketing, 14(1), 57-69. http://dx.doi.org/10.1177/1356766707084219 
McCracken, G. (1986). Culture and consumption: A theoretical account of the structure and movement of the cultural meaning of consumer goods. Journal of Consumer Research, 13(1), 71-84. http://dx.doi.org/10.1086/209048

McCracken, G. (1989). Who is the celebrity endorser? Cultural foundations of the endorsement process. Journal of Consumer Research, 16(3), 310-321. http://dx.doi.org/10.1086/209217

Ohanian, R. (1990). Construction and validation of a scale to measure celebrity endorsers' perceived expertise, trustworthiness, and attractiveness. Journal of Advertising, 19(3), 39-52. http://dx.doi.org/10.1080/00913367.1990.10673191

Petty, R. and Wegener, D. (1999). The Elaboration Likelihood Model: Current Status and Controversies, in Dual-Process Theories in Social Psychology, Shelley Chaiken and Yaacov Trope, eds. New York: Guildford Press, 41-72. http://dx.doi.org/10.4135/9781446249215.n12

Popescu, G. (2014). The economic value of celebrity endorsements: A literature review. Economics, Management, and Financial Markets, 9(4), 119-124.

Pringle, H. (2004). Celebrity Sells. Hoboken: Wiley.

Quester, P. \& Lim, A. (2003). Product involvement/brand loyalty: is there a link? Journal of Product and Brand Management, 12(1), 22-38. http://dx.doi.org/10.1108/10610420310463117

Radighieri, J. and Mulder, M. (2013). The impact of source effects and message valence on word of mouth retransmission. International Journal of Market Research, 56(2), 249-263. http://dx.doi.org/10.2501/IJMR-2013-029

Rich, G.A. (1997). The sales manager as a role model: Effects on trust, job satisfaction and performance of salespeople. Journal of the Academy of Marketing Science, 25(4), 319-328. http://dx.doi.org/10.1177/0092070397254004

Samson, A. (2006). Understanding the buzz that matters: Negative vs. positive word of mouth. International Journal of Market Research, 48(6), 647-657. http://eprints.lse.ac.uk/21883/

Samson, A. (2010). Product usage and firm-generated word of mouth. International Journal of Market Research, 52(4), 459-482.

Sobel, M. E. (1982). Asymptotic confidence intervals for indirect effects in structural equation models. Sociological Methodology, 13, 290-312. http://dx.doi.org/10.2307/270723

Ward, S. (1974). Consumer socialization. Journal of Consumer Research, 1(2), 1-14. http://dx.doi.org/10.1086/208584 
Zeithaml, V.A., Berry, L.L. \& Parasuraman, A. (1996). The behavioural consequences of service quality. Journal of Marketing Management, 60(2), 31-46. http://www.jstor.org/stable/1251929 
